\title{
Mt. Fuji Holocene eruption history reconstructed from proximal lake sediments and high-density radiocarbon dating
}

\author{
S.P. Obrochta ${ }^{\text {a, }}$,, Y. Yokoyama ${ }^{\text {b }}$, M. Yoshimoto ${ }^{\text {c }}$, S. Yamamoto ${ }^{\text {c }}$, Y. Miyairi ${ }^{\text {b }}$, G. Nagano ${ }^{\text {b, }}{ }^{\text {, }}$ \\ A. Nakamura ${ }^{d}$, K. Tsunematsu ${ }^{\text {c, } 2}$, L. Lamair ${ }^{\mathrm{e}}$, A. Hubert-Ferrari ${ }^{\mathrm{e}}$, B.C. Lougheed ${ }^{\mathrm{f}}$, \\ A. Hokanishi ${ }^{g}$, A. Yasuda ${ }^{g}$, V.M.A. Heyvaert ${ }^{\text {h, }}{ }^{\text {, }}$, M. De Batist ${ }^{\mathrm{i}}$, O. Fujiwara ${ }^{\mathrm{d}}$, the \\ QuakeRecNankai Team ${ }^{3}$
}

\footnotetext{
a Akita University Graduate School of International Resource Science, Japan

${ }^{\mathrm{b}}$ University of Tokyo Atmosphere and Ocean Research Institute, Japan

${ }^{c}$ Yamanashi Prefectural Government Mount Fuji Research Institute, Japan

' Geological Survey of Japan, AIST, Japan

e University of Liège Department of Geography, Belgium

${ }^{\mathrm{f}}$ Laboratoire des Sciences du Climat et de l'Environnement LSCE/IPSL, CNRS-CEA-UVSQ Université Paris-Saclay, France

g University of Tokyo Earthquake Research Institute, Japan

${ }^{\mathrm{h}}$ Geological Survey of Belgium, Royal Belgian Institute of Natural Sciences, Belgium

${ }^{\mathrm{i}}$ Ghent University Department of Geology, Belgium
}

\section{A R T I C L E I N F O}

\section{Article history:}

Received 3 June 2018

Received in revised form

29 August 2018

Accepted 1 September 2018

Available online 10 October 2018

\begin{abstract}
A B S T R A C T
An 8000-year lacustrine sediment record from Lake Motosu (Fuji Five Lakes) records several eruptions, including potentially unreported events, of the active Mt. Fuji volcano, which receives approximately 47 million annual visitors. A high-fidelity age model is constructed from tephra ages and high-density radiocarbon dating of terrestrial macrofossil and bulk organic matter. Variability in lake reservoir age is constrained by modern lake water radiocarbon measurement and reverse calibration of tephra calendar ages. We present more accurate ages for known eruptions, detect a wider distribution of ejecta for several eruptions, including the most recent summit eruption, and potentially identify previously undetected flank eruptions. There are closely spaced scoria-fall layers that may be difficult to differentiate as separate events in land-based surveys. These results demonstrate the utility of lacustrine sediments as powerful tools for understanding characteristics of volcanic eruptions.
\end{abstract}

(c) 2018 Elsevier Ltd. All rights reserved.

\section{Introduction}

The Japanese archipelago is distributed along a triple junction at the intersection of the North American, Pacific, and Philippine Sea Plates. The resulting tectonic activity formed Mt. Fuji, an active volcano adjacent to the Tokyo metropolitan area (Fig. 1). Based on data compiled by Shizuoka and Yamanashi Prefectures, the Mt. Fuji area attracted approximately 47 million visitors during 2015.

\footnotetext{
* Corresponding author.

E-mail address: obrochta@gipc.akita-u.ac.jp (S.P. Obrochta).

1 Present address: Geospatial Information Authority of Japan, Ministry of Land, Infrastructure, Transport, and Tourism.

2 Present address: Yamagata University, Faculty of Science, Japan.

3 Members of the QuakeRecNankai Team: Boes, E., Brückner, H., De Rycker, K. Garrett, E., Ono, E., Riedesel, S., Sato, Y., Shishikura, M., and Walstra, J.
}

Volcanic disaster mitigation plans for this region have been developed taking into account historical and geological information, the latter obtained through a number of primarily land-based geological field surveys (e.g., Yamamoto et al., 2005b; Ishizuka et al., 2007) and a small number of lake cores (Koshimizu et al., 2007) from the northwestern flank of Mt. Fuji. Regional stratigraphy is constrained by the presence of four volcanic marker beds, the Aira-Tn, Kikai-Akahoya, Amagi Kawagodaira, and Kozushima Tenjosan, that are derived from well-dated eruptions of distal volcanoes and, in contrast to the typically mafic composition of Mt. Fuji eruption products, comprised of felsic pumice (Fig. 2). The ages of prehistorical Mt. Fuji eruptions are based on radiocarbon dating of primarily charred material taken from within, above, or below volcanic deposits. However, the reported calendar ages are not always consistent with their observed stratigraphic order and position relative to Kawagodaira pumice-fall layer (Yamamoto et al., 


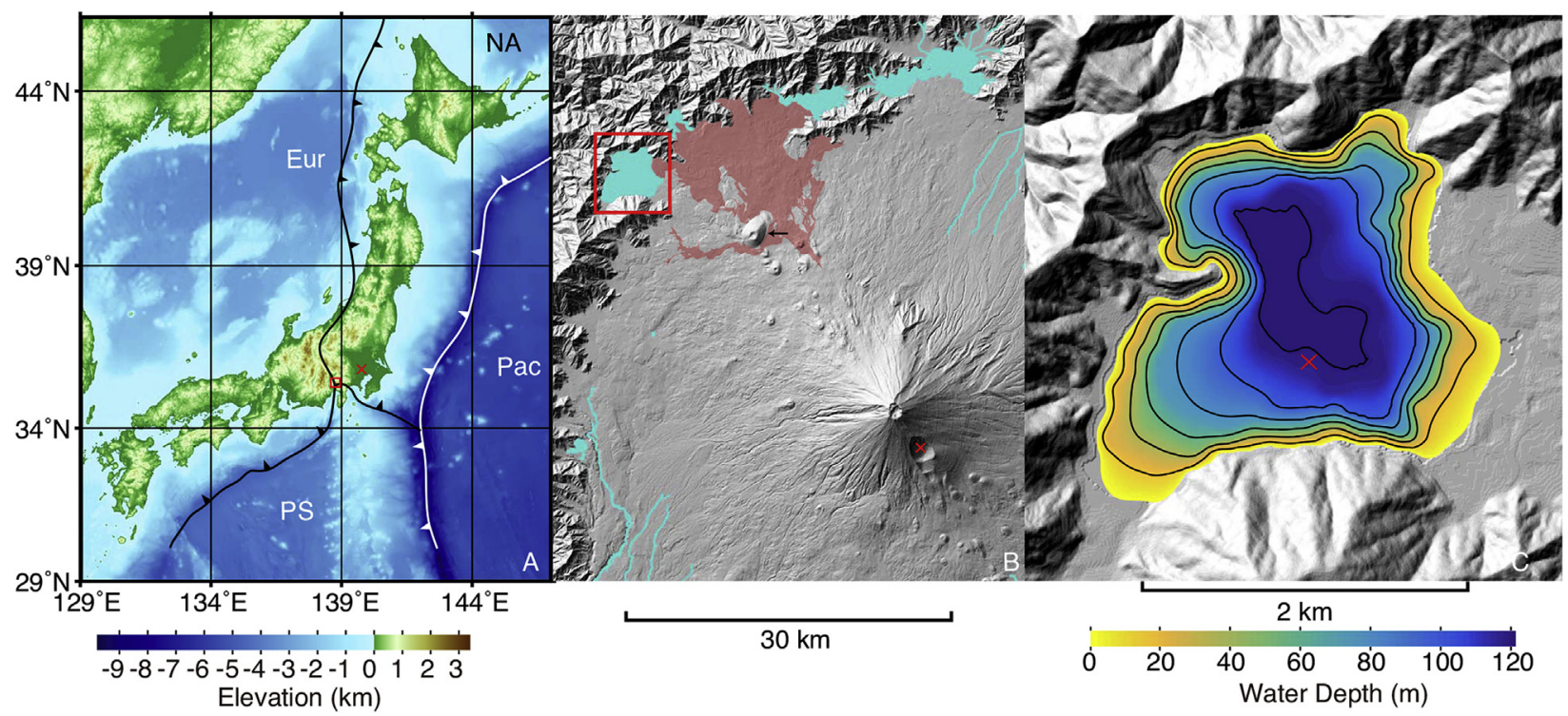

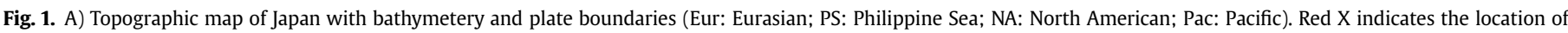

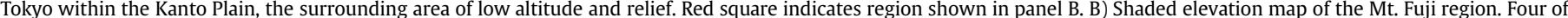

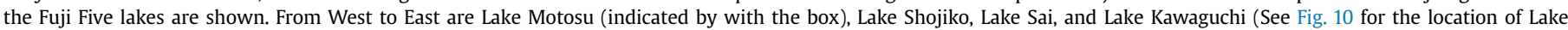

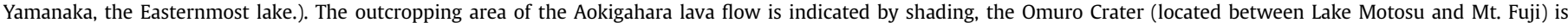

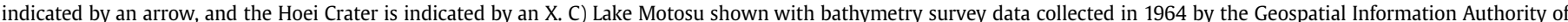

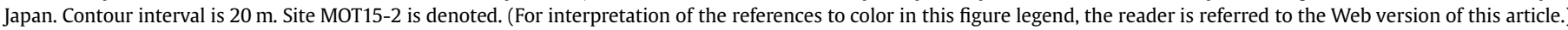
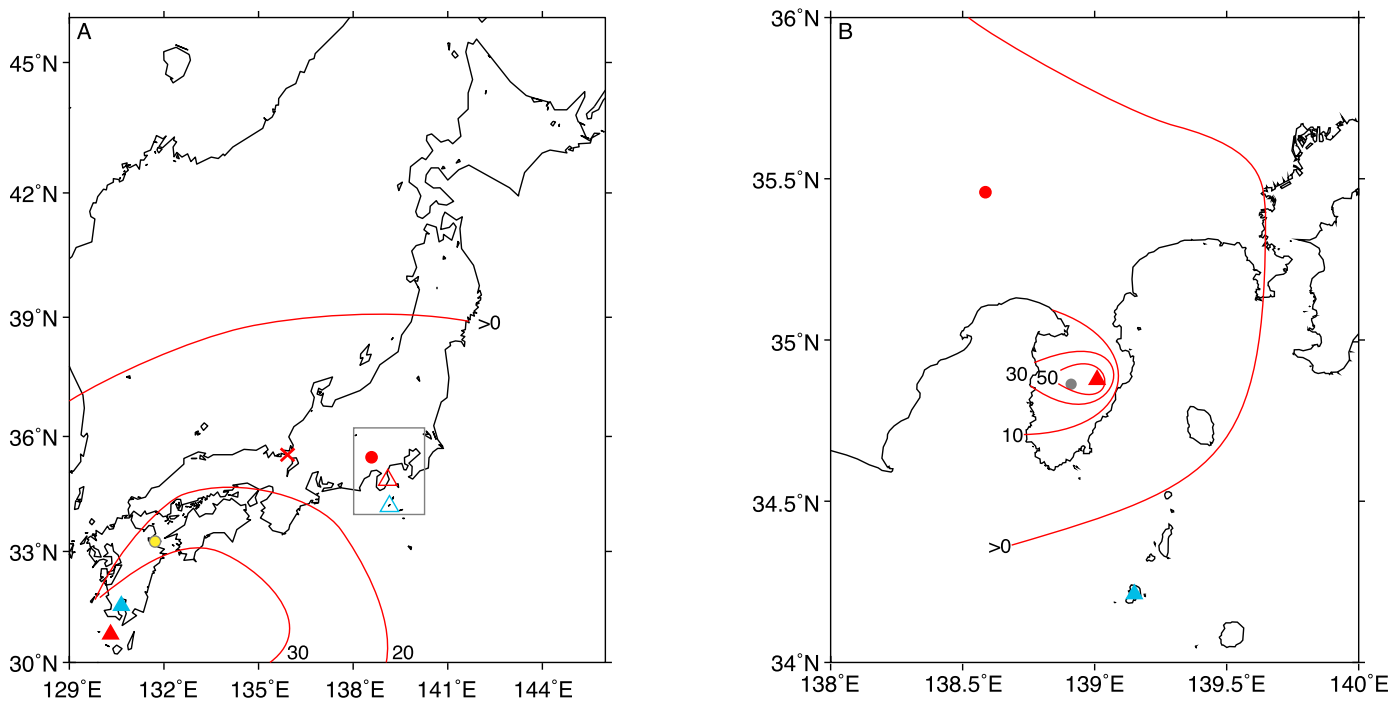

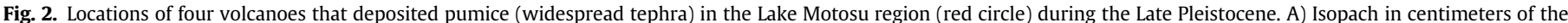

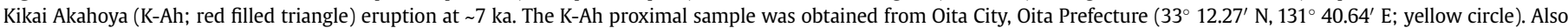

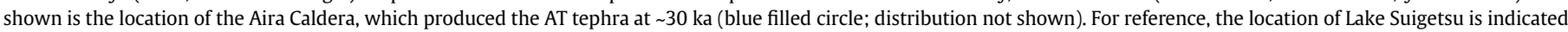

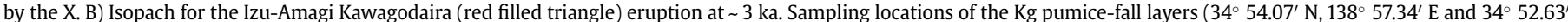

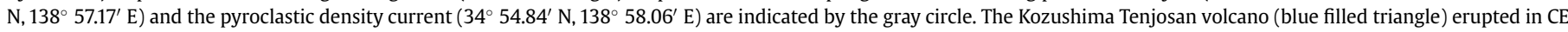

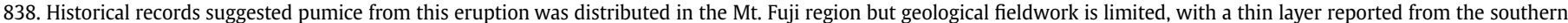

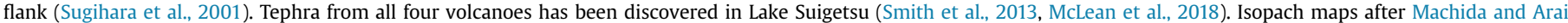
(2003). (For interpretation of the references to color in this figure legend, the reader is referred to the Web version of this article.)

2005b, Fig. 3). The current Mt. Fuji hazard map was created using the best information available at the time (Fuji Hazard Map Committee Members, 2004) and is slated for revision by 2020. Because eruption age and ejecta distribution are fundamental for hazard assessment, increased accuracy in reconstructing Mt. Fuji activity will contribute to improving the regional disaster mitigation plan with respect to eruption scenario and evacuation area.

Recent work has demonstrated the utility of lacustrine sediments in providing more accurate ages for volcanic depositions (e.g., Björck et al., 2006; Van Daele et al., 2014; McLean et al., 2018), particularly when high-density dating is performed (Blaauw et al., 2018). In 2014 and 2015, we carried out a coring campaign at four of the Fuji Five Lakes, Motosu, Sai, Kawaguchi, and Yamanaka. These are tectonically-controlled and distributed in an East-West trend along the Northern flank of the Mt. Fuji volcano. Given the prevailing Northwesterly wind, Lake Yamanaka, located on the Eastern 


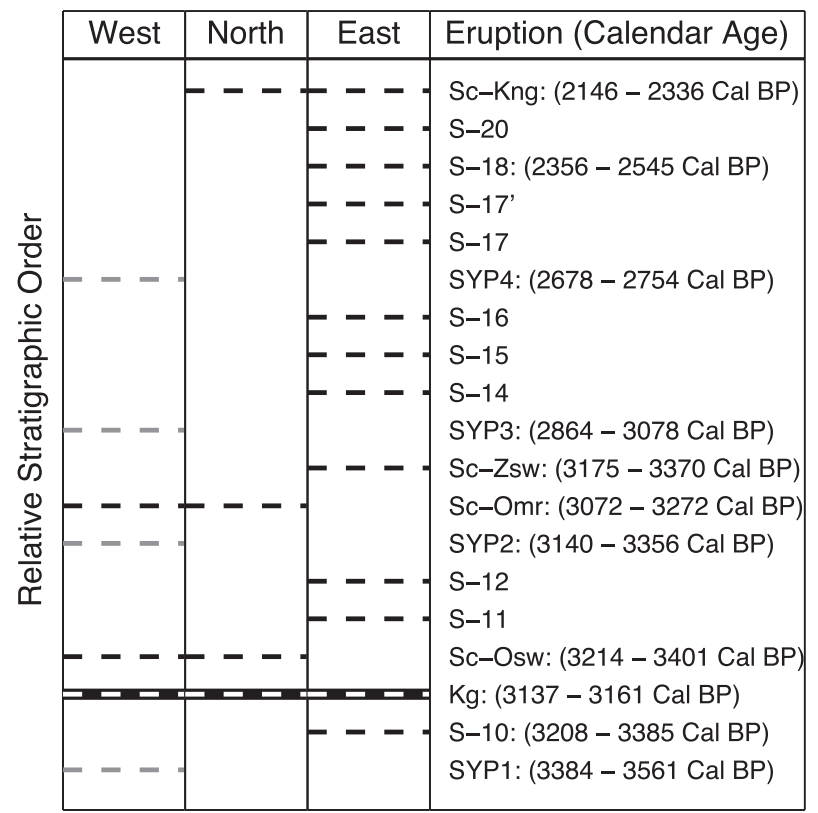

Fig. 3. Relative stratigraphic order of Mt. Fuji eruptions during the Subashiri-C Stage showing scoria-fall deposits (black lines), pyroclastic density currents (gray lines), and the Kawagodaira $(\mathrm{Kg})$ widespread tephra (white and black dashed line). Age of the $\mathrm{Kg}$ eruption from Tani et al. (2013). Ages of Mt. Fuji eruptions are from Yamamoto et al. (2005a; 2005b) and are recalibrated here for consistency with calibrated radiocarbon dates from Lake Motosu using MatCal (Lougheed and Obrochta, 2016) with IntCal13 (Reimer et al., 2013).

flank of the volcano, is situated to record the largest number of eruptions. However, thick, coarse volcanic deposits, impenetrable with a piston corer, resulted in the recovery of only short gravity cores.

We therefore focus on a much longer, apparently continuous record recovered from Lake Motosu (Site MOT15-2) that is dated at centennial-resolution and contains five scoria-fall layers deposited over the past $\sim 3000$ years. Lake Motosu preserves records of paleoenvironmental change, seismic activity, and volcanic eruptions (e.g., Lamair et al., 2018), and with a Westerly relative position, upstream of the prevailing wind direction, it is positioned to record Western flank eruptions and several of the larger summit eruptions. To date, relatively few scoria-fall deposits have been identified along the Northwestern flank of the volcano (Yamamoto et al., 2005b). Thus, their presence would indicate a wider distribution than previously thought and allow us to better evaluate the discrepancy between their reported ages and observed stratigraphic order. The Lake Motosu record shows the potential for the Fuji Five Lakes to refine the chronology of Mt. Fuji eruptions, which could be furthered through rotary drilling of Lake Yamanaka.

\section{Background}

\subsection{Regional marker beds}

The four Late Pleistocene pumice marker beds deposited in the Mt. Fuji region are relatively widespread tephras that are not sourced from Mt. Fuji. The older two of these, the Aira-Tn (AT) and the Kikai-Akahoya (K-Ah) are derived from the Aira and Kikai Calderas on the southern tip of Kyushu, the southernmost of Japan's main islands (Fig. 2A). The younger two tephras are sourced from the Kawagodaira cone of the Amagi volcano and from the Tenjosan dome on the volcanic Kozushima island in the Izu arc, each South of Mt. Fuji. These two volcanoes produced the more regionally- dispersed Kawagodaira pumice $(\mathrm{Kg})$ and the Kozushima-Tenjosan (Iz-Kt) tephra, respectively. All four of these tephras have been identified in Lake Suigetsu in central Japan ( $\left.35^{\circ} 35^{\prime} \mathrm{N}, 135^{\circ} 53^{\prime} \mathrm{E}\right)$, $240 \mathrm{~km}$ from Lake Motosu; The At and K-Ah are deposited in Suigetsu as visible layers (Smith et al., 2013), while the Kg and Iz-Kt are cryptic (McLean et al., 2018).

The age of the AT eruption has been determined by radiocarbon dating on selected organic fractions of charred material retrieved from the pyroclastic density current, obtaining an age of 25,120 \pm 270 ${ }^{14} \mathrm{C}$ yr BP (Miyairi et al., 2004), which calibrates to $28,585-29,871 \mathrm{cal}$ BP $(2 \sigma)$ using IntCal13 (Reimer et al., 2013) and MatCal (Lougheed and Obrochta, 2016). The SG06 Suigetsu varve chronology (Nakagawa et al., 2012) suggests a slightly older age range for the AT eruption (29,820-30,198 cal BP) and an age of 7165-7303 cal BP for the K-Ah eruption (Smith et al., 2013). The age of the Kg eruption has been determined precisely through ${ }^{14} \mathrm{C}$ wiggle matching $(3149 \pm 12$ Cal BP; Tani et al., 2013), and the Iz-Kt is a historical eruption that occurred in 838 CE (e.g., Sugihara et al., 2001).

The $\mathrm{Kg}$ and $\mathrm{K}-\mathrm{Ah}$ tephras are the most relevant for this study (Fig. 2). The AT tephra predates the maximum age of our record. The dispersal pattern of the Iz-Kt is not well established from field studies (Machida and Arai, 2003), but historical records suggest it was deposited in the Mt. Fuji region, and it has been reported to be $\sim 1 \mathrm{~mm}$ thick at a distance of $120 \mathrm{~km}$ from the source volcano (Sugihara et al., 2001). Discovery of the Iz-Kt tephra in Lake Suigetsu (McLean et al., 2018) suggests it is present in Lake Motosu, though likely as a non-visible cryptotephra.

\subsection{Mt. Fuji development}

Two distinct classification schemes using the stratigraphy of lava flows (Tsuya, 1968) and tephra deposits (Machida, 1977) have been proposed to describe the development of Mt. Fuji. Takada et al. (2016) recently reconciled these two schemes and classify the development of Mt. Fuji into three stages over the past $100 \mathrm{ka}$, the Hoshiyama, the Fujinomiya, and the Subashiri.

The Hoshiyama Stage, previously referred to as the Ko- (older) Fuji (Tsuya, 1968), lasted from 100 ka to 17 ka during which explosive eruptions widely distributed large amounts of basaltic tephra over the Kanto Plain. Tsuya (1968) grouped the subsequent two stages, the Fujinomiya and the Subashiri, into the Shin(younger) Fuji Volcano. During the Fujinomiya Stage, lasting from $17 \mathrm{ka}$ to $8 \mathrm{ka}$, volcanic activity was dominated by large-volume lava flows extending up to $40 \mathrm{~km}$ from the summit. The current Subashiri Stage, beginning from $8 \mathrm{ka}$, is subdivided based on differences in eruption style. The Subashiri-A Stage (8-5.6 ka) was marked by reduced activity, with mainly sporadic, modest eruptions. The modern volcanic cone was emplaced during the Subashiri-B Stage (5.6-3.5 ka) as eruptions became more frequent. The Subashiri-C Stage (3.5-2.3 ka) saw explosive basaltic Plinian and sub-Plinian summit eruptions, as well as explosive flank eruptions. Of the over 14 scoria-fall deposits that have been registered in total during this Stage (Miyaji, 1988), only two are detected in the Lake Motosu area (Northwestern flank; Fig. 3). Four pyroclastic density currents (PDCs) flowed down the western flank. These include the first two of the "Shin-Fuji Younger" PDCs (SYP1 and 2) with reported ages (Yamamoto et al., 2005b) of 3384-3561 and 3140-3356 cal BP, between which the Osawa Scoria (Sc-Osw) was deposited (3214-3401 cal BP). An eruption on the northwest flank then created the Omuro scoria-fall deposit (Sc-Omr; 3072-3272 cal BP); it was followed by the deposition of SPY3 and SPY4 (2864-3078 and 2678-2754 cal BP). The last known summit eruption (Kengamine; Sc-Kng) occurred at the end of the Subashiri$C$, with subsequent eruptions limited to flank volcanoes during the Subashiri-D Stage (2.3 ka - present). Two large historic Mt. Fuji 
Table 1

Sediment core coordinates and recovery depths.

\begin{tabular}{|c|c|c|c|c|c|c|c|}
\hline Core & Lat & $\min$ & lon & $\min$ & top (m) & length $(\mathrm{cm})$ & location \\
\hline MOT15-2B-G-1 & 35 & 27.69 & 138 & 35.156 & 0 & 32 & Japan \\
\hline MOT15-2A-G-1 & 35 & 27.69 & 138 & 35.156 & 0 & 27 & Belgium \\
\hline MOT15-2D-H-1 & 35 & 27.684 & 138 & 35.155 & 0 & 184 & Japan \\
\hline MOT15-2A-H-1 & 35 & 27.683 & 138 & 35.154 & 0 & 185 & Belgium \\
\hline MOT15-2E-H-1 & 35 & 27.686 & 138 & 35.159 & 1 & 189 & Japan \\
\hline MOT15-2C-H-1 & 35 & 27.683 & 138 & 35.156 & 1 & 187 & Belgium \\
\hline MOT15-2B-H-1 & 35 & 27.684 & 138 & 35.154 & 2 & 157 & Split (Japan/Belgium) \\
\hline
\end{tabular}

eruptions have occurred. The AD 864-866 Jogan eruption resulted in the Aokigahara Lava flow extending into Lake Motosu. In AD 1707, the Hoei eruption occurred on the southeastern flank.

\subsection{Lake Motosu}

Lake Motosu ( $35^{\circ} 27.833^{\prime} \mathrm{N}, 138^{\circ} 35.167^{\prime} \mathrm{E}$; $900 \mathrm{~m}$ asl; Fig. 1 ) is situated directly proximal to the Mt. Fuji volcano and is the deepest of the Fuji Five Lakes. The last bathymetric survey was conducted in 1964, during which time the maximum depth and basin size were reported to be $121.6 \mathrm{~m}$ and $4.7 \mathrm{~km}^{2}$, respectively (Geospatial Information Authority of Japan, 2018). The AT tephra was identified in a deep borehole along the eastern shore of the lake at a depth of $172 \mathrm{~m}$ overlying lake sediments, indicating Lake Motosu has existed since at least $\sim 30 \mathrm{ka}$ (Koshimizu et al., 2007).

Hamada et al. (2012) performed 18 monthly hydrographic surveys between May 2009 and October 2010, sampling between a depth of $110 \mathrm{~m}$ and the surface. During this time, the lake was stratified except during February and March. Hamada et al. (2012) also estimated the catchment size to be between 24.64 and $9.81 \mathrm{~km}^{2}$ and calculated water balance, reporting $\sim 1500 \mathrm{~mm} / \mathrm{y}$ and between $\sim 200$ and $\sim 475 \mathrm{~mm} / \mathrm{y}$ of water input by direct rainfall and groundwater percolation, respectively. This was balanced by evaporation of $\sim 600 \mathrm{~mm} / \mathrm{y}$, removal of $\sim 530 \mathrm{~mm} / \mathrm{y}$ for hydroelectric power generation, and groundwater outflow of between $\sim 560$ and $850 \mathrm{~mm} / \mathrm{y}$. There is no year-round, sustained river input.

\section{Methods}

\subsection{Coring and stratigraphic correlation}

Two gravity and seven hammer-piston sediment cores were recovered from Lake Motosu in November 2015 using an Uwitec platform (Table 1; Fig. 4). Two-meter piston cores were recovered at overlapping depths below the lake floor (e.g., $0-2 \mathrm{~m}, 1-3 \mathrm{~m}$, $2-4 \mathrm{~m}$ ) by adding extensions to the core barrel. Duplicate cores were retrieved to a depth of $3 \mathrm{~m}$, with one set of cores being transported to Belgium where they were split for parallel analyses. The piston core from 2 to $4 \mathrm{~m}$ was not duplicated and split in the field. One half was transported to Belgium. Cores remaining in Japan were split at the Yamanashi Prefecture Mount Fuji Research Institute and immediately imaged and described.

Color reflectance (i.e., $\mathrm{L}^{*}, \mathrm{a}^{*}, \mathrm{~b}^{*}$ ) was calculated from the core images (e.g., Obrochta et al., 2014). Cores in Japan were analyzed by $\mathrm{X}$-Ray fluorescence (XRF) at the Kochi Core Center using an ITRAX XRF scanner set to $30 \mathrm{kV}$ with a $1 \mathrm{~cm}$ step and a Hitachi Pratico CT Scanner, respectively. XRF data from cores transported to Belgium were collected with an Aavatech Core Scanner III at the MARUM, University of Bremen with a 2-mm step over a $1.2 \mathrm{~cm}^{2}$ area and a down-core slit size of $2 \mathrm{~mm}$ at $30 \mathrm{kV}$. A composite, spliced section for the Japanese cores was constructed through visual stratigraphic correlation, aided by the XRF and color reflectance data, to create a continuous record to $3.67 \mathrm{~m}$ composite depth (mcd; Table 2). The depth scales of the Belgian cores were then reprojected to precisely align them to the Japanese composite splice.

\subsection{Widespread tephra analysis}

Two visible, rhyolitic pumice layers (not of Mt. Fuji origin) at $1.915 \mathrm{mcd}$ (5-10 mm thick; MOT15-2D-H1 $186 \mathrm{~cm}$ ) and $3.455 \mathrm{mcd}$ $(\sim 5 \mathrm{~mm}$ thick; MOT15-2B-H1 $135 \mathrm{~cm})$ are present. Based on reported tephra thickness, distribution, and age, these are likely to be the $\mathrm{Kg}(3149 \pm 12$ cal BP; Tani et al., 2013) and K-Ah $(7234 \pm 69$ cal BP; Smith et al., 2013) tephras. To confirm this, geochemical

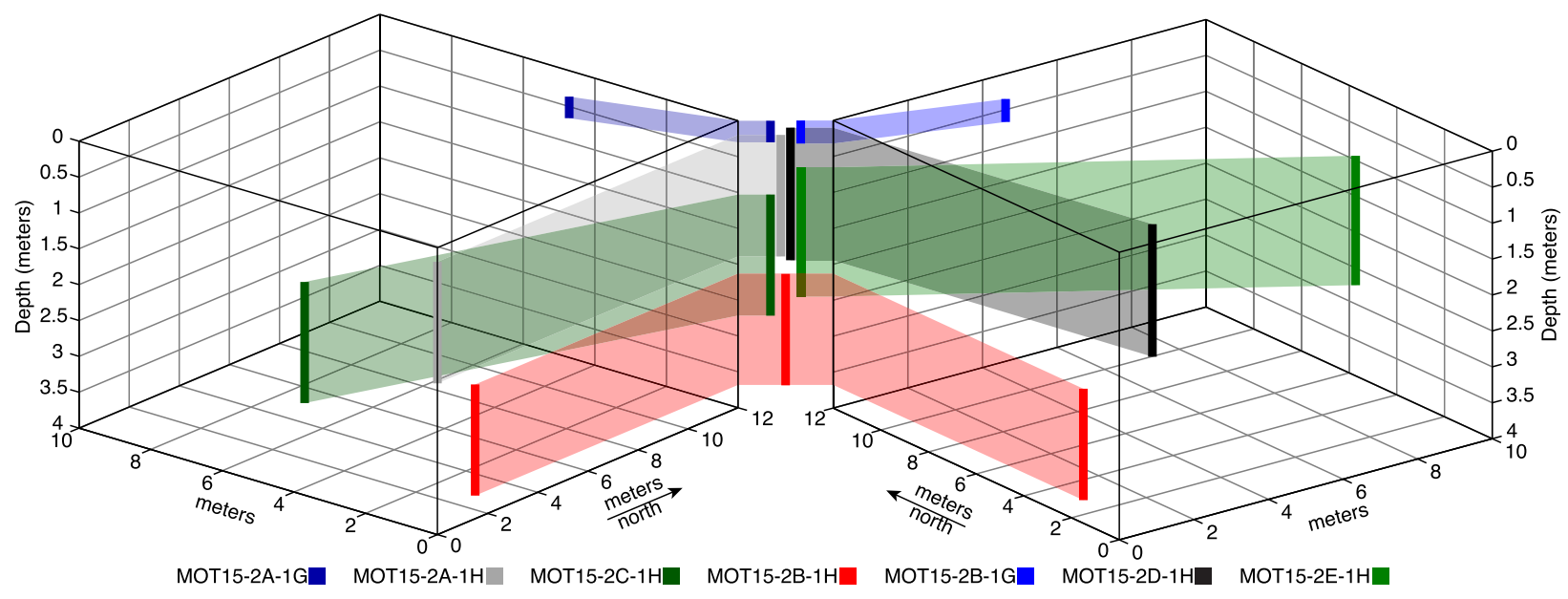

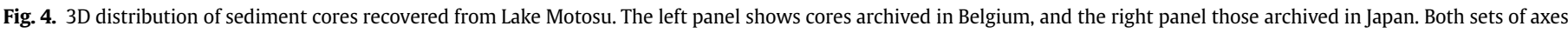
are centered on the same geographic coordinates. Visual stratrigraphy and XRF data were used to align the cores archived in Belgium to the Japanese cores. 
Table 2

Composite splice table.

\begin{tabular}{cc|c|c|c|c|c} 
Core & Interval $(\mathrm{cm})$ & tie type & Core & Interval $(\mathrm{cm})$ & Length $(\mathrm{cm})$ & Depth $(\mathrm{mcd})$ \\
\hline \hline & & start & MOT15-2B-1G & 15 & & 0 \\
MOT15-2B-1G & 35 & tie to & MOT15-2D-1H & 14.5 & 20 & 0.2 \\
MOT15-2D-1H & 187 & tie to & MOT15-2E-1H & 129 & 172.5 & 1.925 \\
MOT15-2E-1H & 182 & tie to & MOT15-2B-1H & 35 & 53 & 2.455 \\
MOT15-2B-1H & 159 & end & & 124 & 3.695 \\
\hline \hline
\end{tabular}

analysis of 10 glass shards from each tephra was performed by electron probe microanalysis (EPMA) at Earthquake Research Institute (University of Tokyo). A JEOL-8800 microprobe was used with a15 KeV potential, $12 \mathrm{nA}$ current, and $10 \mu \mathrm{m}$ beam width for 40 s (e.g., Suzuki et al., 2013). Columbia River Basalt (USGS BCR-2) was used as a secondary standard. Measured components are $\mathrm{Na}_{2} \mathrm{O}, \mathrm{MgO}, \mathrm{SiO}_{2}, \mathrm{P}_{2} \mathrm{O}_{5}, \mathrm{SO}_{3}, \mathrm{Cl}, \mathrm{Al}_{2} \mathrm{O}_{3}, \mathrm{~K} 2 \mathrm{O}, \mathrm{CaO}, \mathrm{FeO}, \mathrm{TiO}_{2}$, and $\mathrm{V}_{2} \mathrm{O}_{3}$. Shards collected proximal to each volcano were also analyzed for comparison to the unknown tephras in the sediment cores. The $\mathrm{Kg}$ pyroclastic density current was sampled ( $34^{\circ} 54.84^{\prime} \mathrm{N}, 138^{\circ} 58.06^{\prime}$ $\mathrm{E}$ ), and the $\mathrm{Kg}$ pumice-fall layer was sampled at two locations (34 $54.07^{\prime} \mathrm{N}, 138^{\circ} 57.34^{\prime} \mathrm{E}$ and $\left.34^{\circ} 52.63^{\prime} \mathrm{N}, 138^{\circ} 57.17^{\prime} \mathrm{E}\right)$. The K-Ah tephra was sampled from Oita City, Oita Prefecture $\left(33^{\circ} 12.27^{\prime} \mathrm{N}\right.$, $131^{\circ}$ 40.64’ E; Fujiwara et al., 2010).

\subsection{Chronology}

\subsubsection{Radiocarbon analyses}

Radiocarbon analyses of terrestrial macrofossils, bulk organic matter, and modern lake water were performed at the Atmosphere and Ocean Research Institute, The University of Tokyo, using a single stage accelerator mass spectrometer (AMS) following the procedures described in Yamane et al. (2014) and Yokoyama et al. (2016). Lake water samples were immediately spiked with $\mathrm{HgCl}_{2}$. Radiocarbon ages were calibrated using MatCal (Lougheed and Obrochta, 2016) and the IntCal13 calibration curve (Reimer et al., 2013). Bulk samples were corrected for reservoir effect (due to the contribution of relatively older carbon) as described in the next section. For a portion of the bulk radiocarbon dates, $\mathrm{C} / \mathrm{N}$ data was obtained during the radiocarbon analyses.

\subsubsection{Bulk organic matter radiocarbon correction}

To investigate the influence of older carbon upon bulk radiocarbon dates (the so-called reservoir effect), bulk organic matter ${ }^{14} \mathrm{C}$ dates were performed at depths coinciding with the depths ( $1.915 \mathrm{mcd}$ and $3.455 \mathrm{mcd}$ ) of the two widespread tephras of known calendar age. The calendar ages of the tephras were reverse calibrated into an expected ${ }^{14} \mathrm{C}$ age probability density function (PDF) according to the IntCal13 (Reimer et al., 2013) calibration curve using the methodology described in Lougheed et al. (2017). The reservoir effect offset was calculated as the difference between the actual median ${ }^{14} \mathrm{C}$ ages according to the reverse calibration process. Uncertainty was calculated as the difference in the continuous $1 \sigma$ ranges of the radiocarbon year PDFs. The root sum of squared uncertainty for the analytical age and the offset was calculated and applied to each bulk date prior to calibration. For bulk dates between 1.915 mcd and 3.455, reservoir age and uncertainty was linearly interpolated. Along with the age of the modern lake water, this provides three points for assessing the old carbon-induced reservoir effect for bulk ${ }^{14} \mathrm{C}$ dates.

\subsubsection{Age modeling}

Age modeling was performed in a deterministic $10^{5}$ iteration
Monte Carlo routine, called "undatable", that considers depth uncertainty and was adapted from Obrochta et al. (2017). The model was further modified in Webster et al. (2018) to include Gaussian accumulation rate uncertainty between adjacent dates by adding intermediate points in between age-depth points. Anchoring is also included to prevent the modeled median from drifting away from the region of highest probability of the upper- and lower-most dates, which is a consequence of including depth uncertainty. Material for bulk dates was subsampled from 2-cm samples, but the precise sample depth is uncertain because only a small amount of sediment was needed for dating. An initial 2000-iteration run was performed by the same method as the primary simulation (described below) to obtain the top and bottom anchor points. These are extrapolated points based on the median age and depth of the upper- and lower-most two dates.

Bulk dates from the same levels as the tephras were excluded for a total of 31 dates used in the model. The modeling strategy uses the relatively precise macrofossil $(n=5)$ and tephra ages $(n=2)$ to anchor the less-well constrained bulk dates $(n=24)$ by bootstrapping the bulk dates, retaining $50 \%$ of all data for each iteration (i.e., 15 dates, always including each macrofossil and tephra). For each iteration, age-depth modeling was performed in an upwards direction from the stratigraphically lowest date by selecting one probability-weighted age from the $95.4 \%(2 \sigma)$ age range of each calendar age PDF and, in the case of bulk dates, one randomly sampled depth from the uniformly-distributed depth PDF. Dates producing age reversals are automatically skipped (i.e. regarded as an outlier) in an iteration if resampling of the PDF does not clear the reversal.

Results of the modeling are stored in a $63 \times 2 \times \mathrm{n}$ matrix, where the first dimension corresponds to the number of dates (31), plus the additional points for added accumulation rate uncertainty between dates (30) and the two anchors. The second dimension holds the sampled age and depth, and $\mathrm{n}$ is the number of simulations. After all simulations were completed, the anchors were discarded and the median depth and age were calculated. Finally, results were interpolated to a $1-\mathrm{cm}$ resolution and a probability density cloud was created by looping through the modeled ages to calculate the 1st through 99th percentiles. Model details and performance are discussed in Lougheed and Obrochta (submitted).

\section{Results}

\subsection{Sediment character}

Sediments at Site MOT15-2 are characterized by a mixture of siliceous biogenic and fine clastic particles punctuated by coarser dark layers rich in scoria with increased $\mathrm{Ca}, \mathrm{Sr}$, and $\mathrm{Ti}$ content relative to background sediment. Lake Motosu is virtually devoid of $\mathrm{CaCO}_{3}$ sediments. Scoria grains were subsampled from split cores and observed with a reflected light microscope to determine grain morphology and if coatings are present. These detailed observations of the scoria layers indicate that five are comprised of angular, 


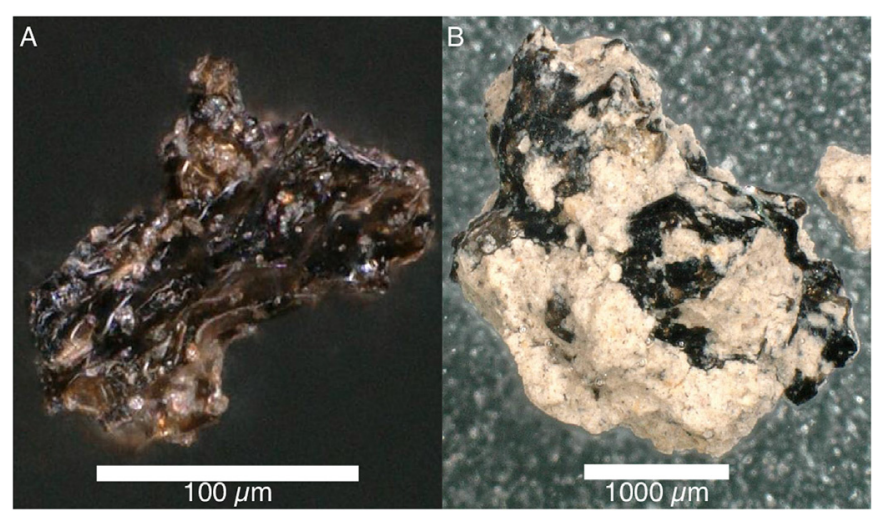

Fig. 5. A) photomicrograph of a clean, non-rounded scoria grain interpreted as being deposited by air-fall from MOT15-2E-1H (116 cm, $1.84 \mathrm{mcd})$. Scale bar is $100 \mu \mathrm{m}$. B) A scoria grain coated with fine sediment that is interpreted to have been reworked (MOT15-2B-1H; $118 \mathrm{~cm}, \sim 3.26 \mathrm{mcd}$ ). Scale bar is $1 \mathrm{~mm}$.

clean scoria (Fig. 5A) that are interpreted to have been deposited by air-fall. The other scoria layers appear reworked and contain 1) rounded grains suggesting transportation, 2) fine sediment embedded in vesicles, and 3) presence of vegetation and terrigenous material (Fig. 5B; e.g., Bertrand et al., 2014). The fall-deposits are preserved in Core MOT15-2D-1H, used in the composite splice, as well as in the off-splice interval of MOT15-2E-1H. 1-cm and $\sim 0.75-\mathrm{cm}$ thick fall-deposits occurs at 1.84 and $1.75 \mathrm{mcd}$. There is a $\sim 5$-cm layer of reworked material directly overlying the 1.75 -mcd fall-deposit. Two mm-scale distinct fall-deposits appear at 1.44 and $1.43 \mathrm{mcd}$, followed a $\sim 1-\mathrm{cm}$ reworked scoria layer. The uppermost scoria fall-deposit is a $\sim 0.5-\mathrm{cm}$ scoria at $1.34 \mathrm{mcd}$.

\subsection{Tephra analysis}

The chemical composition of glass shards from the 1.915 mcd and 3.455 mcd tephras is indistinguishable from the shards sampled proximal to each volcano for the $\mathrm{Kg}$ and $\mathrm{K}$-Ah eruptions, respectively (Fig. 6; See Supplemental online material). Relative to Smith et al. (2013), our data show slightly elevated silica content, perhaps indicating some loss of sodium, though silica content is similar to that of Machida and Arai (2003). This is likely due to difference in beam currents for analyses performed in Japan. The positive identification of the $\mathrm{Kg}$ and $\mathrm{K}$-Ah tephras in these cores is consistent with the reported ages of the eruptions, as well as with the known distribution of ejecta.

\subsection{Chronology}

The radiocarbon age of the lake surface water is $222 \pm 70{ }^{14} \mathrm{C}$ years. Bulk, uncalibrated radiocarbon dates are consistently offset from terrestrial macrofossils and reverse-calibrated tephras (Fig. 7A; Table 3). Correction using the measured age of the lake water results in good agreement to a depth of $\sim 2 \mathrm{mcd}$, at which additional offset is detected between the Kg tephra and the corresponding bulk date (Fig. 7B). Similar offset is observed between the K-Ah tephra age and the bulk date from the same depth. At the levels of the $\mathrm{Kg}$ and $\mathrm{K}$-Ah tephras, bulk dates are offset by an additional $414 \pm 66$ and $503 \pm 118$ years (Fig. 8 A and B). This is added to the $222 \pm 70$ years measured from the modern lake water to obtain a down-core correction for all bulk dates (Fig. 8C). The $\mathrm{C} / \mathrm{N}$ data obtained during AMS measurements show generally low values ( 9), indicative of primarily aquatic organic matter (Fig. 8D). Thus, this offset is interpreted to primarily result from a reservoir age within the lake. After reservoir correction of all bulk dates,

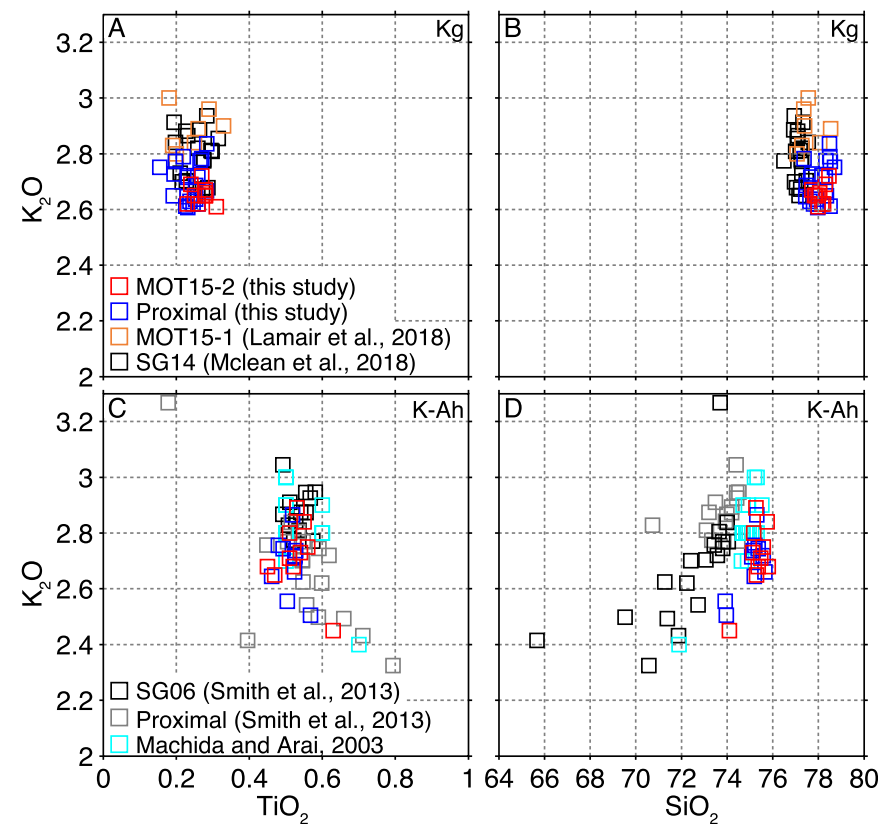

Fig. 6. Geochemistry of glass shards from MOT15-2 (red, this study). A and $B$ ) $\mathrm{K}_{2} \mathrm{O}$ versus $\mathrm{TiO}_{2}$ and $\mathrm{K}_{2} \mathrm{O}$ versus $\mathrm{SiO}_{2}$ for the 1.915 -mcd pumice compared to data from shards collected proximal to the Kawagodaira (Kg) caldera (blue, this study), shards from Site MOT15-1 (orange, Lamair et al., 2018), and from Lake Suigetsu (black, McLean et al., 2018). C and D) The same for the 3.455-mcd pumice (red, this study) compared to proximal shards from the Kikai-Akahoya (K-Ah) eruption (blue, this study; gray, Smith et al., 2013; cyan, Machida and Arai, 2003) and distal shards subsampled from Lake Suigetsu sediment cores (black, Smith et al., 2013). Results indicate that these two pumices are from the $\mathrm{Kg}$ and $\mathrm{K}$-Ah eruptions, which are well-constrained in age. Colors and axes ranges are consistent across all four panels. (For interpretation of the references to color in this figure legend, the reader is referred to the Web version of this article.)

there is good agreement between all bulk dates and tephras, except around 2.5 mcd where bulk dates are anomalously old (Fig. 8E). Age increases linearly with depth until a depth of $\sim 3 \mathrm{mcd}$, at which sedimentation rate appears to decrease.

Age modeling results (Fig. 9) in an age of 380 cal BP (118-692 $2 \sigma$ ) at $0.01 \mathrm{mcd}$, the depth of the uppermost radiocarbon date yr BP. An age of 8172 cal BP $(8375-90602 \sigma)$ is obtained at $3.615 \mathrm{mcd}$, the depth of the lowermost date. The age model produces mean and maximum sediment accumulation rates of $\sim 55$ and $\sim 105 \mathrm{~cm} / \mathrm{ky}$, with a minima $<10 \mathrm{~cm} / \mathrm{ky}$ at the bottom of the spliced section. The modeled mean excludes the reversing age just below $2.5 \mathrm{mcd}$, with asymmetrical uncertainty skewed to older dates in this interval and at the sedimentation rate inflection point.

\section{Discussion}

Combining high-density dating, with an average of approximately one age control point per $10 \mathrm{~cm}$, down-core reservoir age assessment, and a newly developed age model with improved treatment of uncertainty, we obtain a high-fidelity chronology for Site MOT15-2. This allows us to determine robust age ranges for the five scoria-fall layers deposited in apparently continuously accumulating background sediment during the Subashiri-C Stage. Previous work reconstructing volcanic history from lacustrine sediments was aided by the presence of annual laminations (Van Daele et al., 2014; Smith et al., 2013). However, we find that in the absence of varves, the needed chronological control may be obtained through multiple radiocarbon dates (e.g., Blaauw et al., 2011, 2018), particularly when augmented with terrestrial 

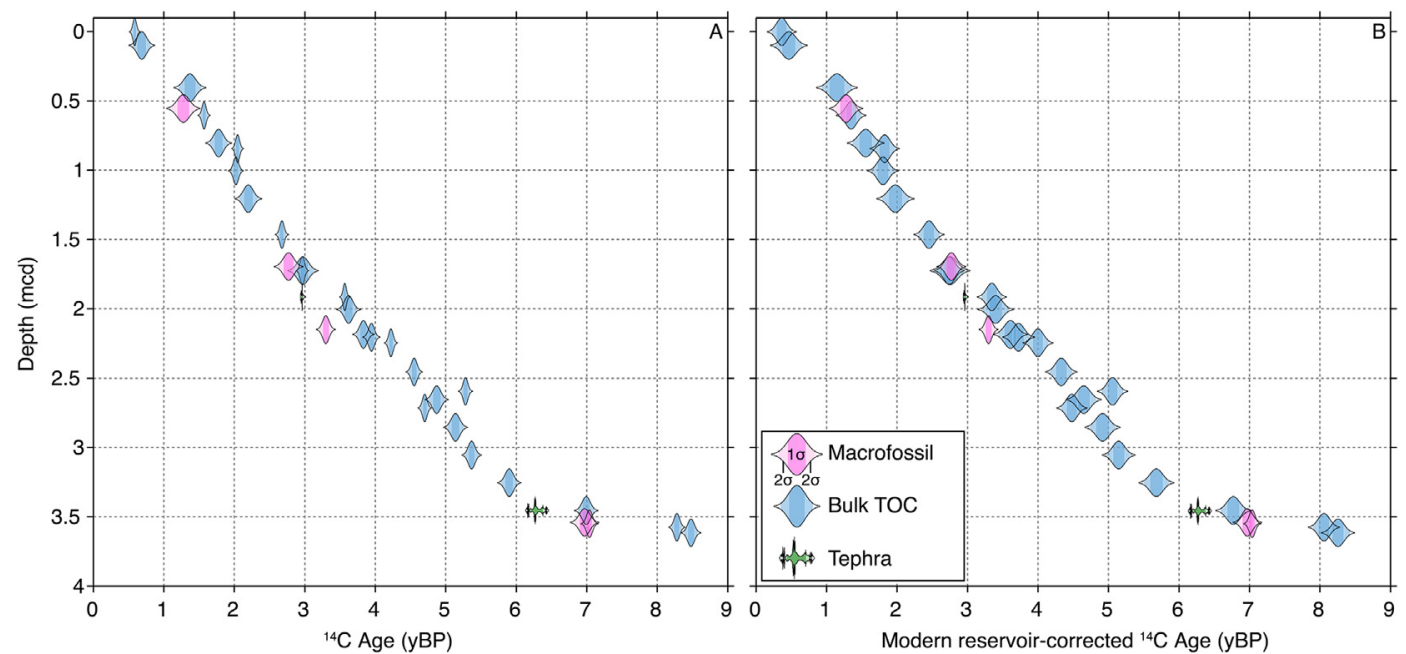

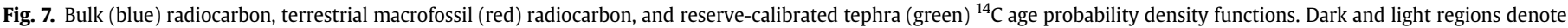

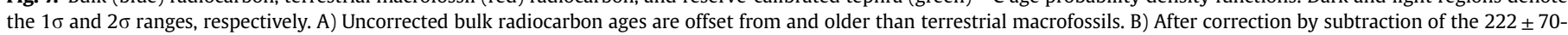

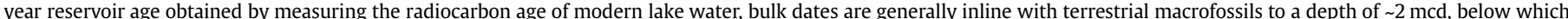

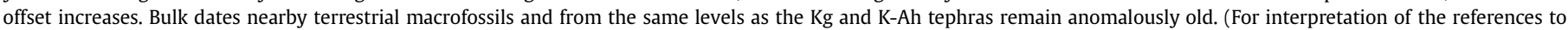
color in this figure legend, the reader is referred to the Web version of this article.)

Table 3

Radiocarbon dating for Site MOT15-2.

\begin{tabular}{|c|c|c|c|c|c|c|c|c|c|c|c|}
\hline Lab ID & top (mcd) & bot (mcd) & 14C age & $14 \mathrm{C}$ err & $\mathrm{C} / \mathrm{N}$ & Cal curve & $\mathrm{R}(\mathrm{t})$ & $\mathrm{R}(\mathrm{t})$ err & $\begin{array}{l}\text { Median } \\
\text { (cal BP) }\end{array}$ & 95.4\% HPD intervals & 95.4\% HPD intervals \\
\hline YAUT-033229 & 0 & 0.02 & 587 & 25 & 9.16 & intcal13 & 222 & 70 & 406 & $527-289(0.955)$ & \\
\hline YAUT-027014 & 0.09 & 0.11 & 688 & 65 & 10.44 & intcal13 & 222 & 70 & 495 & $650-581(0.15)$ & $569-309(0.804)$ \\
\hline YAUT-027216 & 0.395 & 0.415 & 1370 & 82 & & intcal13 & 222 & 70 & 1077 & $1292-905$ (0.937) & $856-830(0.015)$ \\
\hline YAUT-027209 & 0.555 & 0.555 & 1277 & 87 & & intcal13 & 0 & 0 & 1195 & $1338-1047(0.908)$ & $1033-985(0.047)$ \\
\hline YAUT-027306 & 0.595 & 0.615 & 1571 & 28 & 12.27 & intcal13 & 222 & 70 & 1268 & $1393-1171(0.872)$ & $1162-1077(0.083)$ \\
\hline YAUT-027224 & 0.795 & 0.815 & 1778 & 65 & & intcal13 & 222 & 70 & 1459 & $1692-1666(0.02)$ & $1628-1294(0.934)$ \\
\hline YAUT-033231 & 0.835 & 0.855 & 2047 & 28 & 9.74 & intcal13 & 222 & 70 & 1755 & $1899-1566(0.947)$ & \\
\hline YAUT-027309 & 0.995 & 1.015 & 2023 & 36 & 11.47 & intcal13 & 222 & 70 & 1727 & $1894-1552(0.955)$ & \\
\hline YAUT-027217 & 1.195 & 1.215 & 2199 & 68 & & intcal13 & 222 & 70 & 1935 & $2297-2263(0.015)$ & 2157-1699 (0.939) \\
\hline YAUT-027311 & 1.455 & 1.475 & 2676 & 31 & & intcal13 & 222 & 70 & 2539 & $2725-2353(0.955)$ & \\
\hline YAUT-027212 & 1.695 & 1.695 & 2770 & 73 & & intcal13 & 0 & 0 & 2879 & $3059-3046(0.015)$ & $3044-2754(0.941)$ \\
\hline YAUT-027016 & 1.715 & 1.735 & 2975 & 78 & & intcal13 & 222 & 70 & 2880 & $3180-2711(0.952)$ & \\
\hline YAUT-027312 & 1.715 & 1.735 & 2965 & 30 & & intcal13 & 222 & 70 & 2854 & $3035-3011(0.018)$ & $3008-2744(0.933)$ \\
\hline YAUT-034928 & 1.91 & 1.92 & 3567 & 23 & & intcal13 & 636 & 94 & 3085 & $3351-2856(0.955)$ & \\
\hline YAUT-027017 & 1.995 & 2.015 & 3622 & 59 & 11.01 & intcal13 & 641 & 97 & 3148 & $3402-2861(0.949)$ & \\
\hline YAUT-026935 & 2.15 & 2.15 & 3299 & 46 & & intcal13 & 0 & 0 & 3525 & $3637-3445(0.932)$ & $3426-3407(0.023)$ \\
\hline YAUT-027633 & 2.175 & 2.195 & 3832 & 52 & 9.56 & intcal13 & 652 & 102 & 3398 & $3687-3662(0.012)$ & $3646-3137(0.925)$ \\
\hline YAUT-027532 & 2.195 & 2.215 & 3946 & 41 & & intcal13 & 653 & 102 & 3532 & $3830-3329(0.936)$ & $3291-3256(0.019)$ \\
\hline YAUT-033232 & 2.235 & 2.255 & 4222 & 31 & 9.91 & intcal13 & 655 & 103 & 3867 & $4152-3585(0.955)$ & \\
\hline YAUT-027437 & 2.445 & 2.465 & 4552 & 40 & 9.20 & intcal13 & 667 & 109 & 4306 & $4789-4763(0.01)$ & $4627-3971(0.941)$ \\
\hline YAUT-033233 & 2.585 & 2.605 & 5280 & 33 & 9.46 & intcal13 & 675 & 113 & 5295 & $5589-4961(0.954)$ & \\
\hline YAUT-027438 & 2.645 & 2.665 & 4871 & 58 & 9.58 & intcal13 & 679 & 115 & 4714 & $5062-4408(0.936)$ & \\
\hline YAUT-033236 & 2.705 & 2.725 & 4702 & 32 & 9.10 & intcal13 & 682 & 116 & 4511 & $4835-4225(0.931)$ & $4203-4176(0.016)$ \\
\hline YAUT-027439 & 2.845 & 2.865 & 5138 & 60 & 9.43 & intcal13 & 690 & 120 & 5095 & $5471-4815(0.942)$ & \\
\hline YAUT-027502 & 3.045 & 3.065 & 5367 & 48 & 8.88 & intcal13 & 702 & 126 & 5373 & $5657-4966(0.955)$ & \\
\hline YAUT-027503 & 3.245 & 3.265 & 5901 & 58 & 9.42 & intcal13 & 713 & 131 & 5959 & $6276-6226(0.039)$ & $6224-5657(0.915)$ \\
\hline YAUT-027504 & 3.445 & 3.465 & 6993 & 58 & 8.50 & intcal13 & 725 & 137 & 7166 & $7441-6796(0.953)$ & \\
\hline YAUT-027206 & 3.54 & 3.54 & 6970 & 72 & & intcal13 & 0 & 0 & 7803 & $7940-7675(0.955)$ & \\
\hline YAUT-029402 & 3.545 & 3.555 & 7039 & 41 & & intcal13 & 0 & 0 & 7879 & $7956-7790(0.955)$ & \\
\hline YAUT-033237 & 3.565 & 3.585 & 8279 & 39 & & intcal13 & 725 & 137 & 8358 & $8609-8033$ (0.949) & \\
\hline YAUT-027516 & 3.605 & 3.625 & 8479 & 48 & & intcal13 & 725 & 137 & 8579 & $9000-8325(0.955)$ & \\
\hline
\end{tabular}

macrofossils and tephra ages.

Although ejecta from three Subshiri-C Mt. Fuji eruptions, the Kengamine, Omuro, and Osawa (Fig. 3), is deposited along the northwestern side of the volcano, previous work (Miyaji, 1988) suggests erupted material is not distributed over Lake Motosu (Fig. 10). However, Lamair et al. (2018) geochemically analyzed scoria deposited in Lake Motosu and interpreted that it is sourced from Mt. Fuji. Nearby Lake Motosu, the only known volcanoes producing basaltic eruptions over the past 4000 years are Mt. Fuji, Izu-Oshima, and Miyake-Jima, but eruption products from the latter two volcanoes has not been observed in the Mt. Fuji region (Machida and Arai, 2003). We therefore interpret that Lake Motosu records five Mt. Fuji eruptions at median ages and $2 \sigma$ ranges of 3042 (2858-3119 cal BP), 2930 (2798-3072 cal BP), 2458 $(2165-2676 \mathrm{cal}$ BP), 2438 (2145-2658 cal BP), and 2309 (2033-2572 cal BP; Table 4; Fig. 11). 

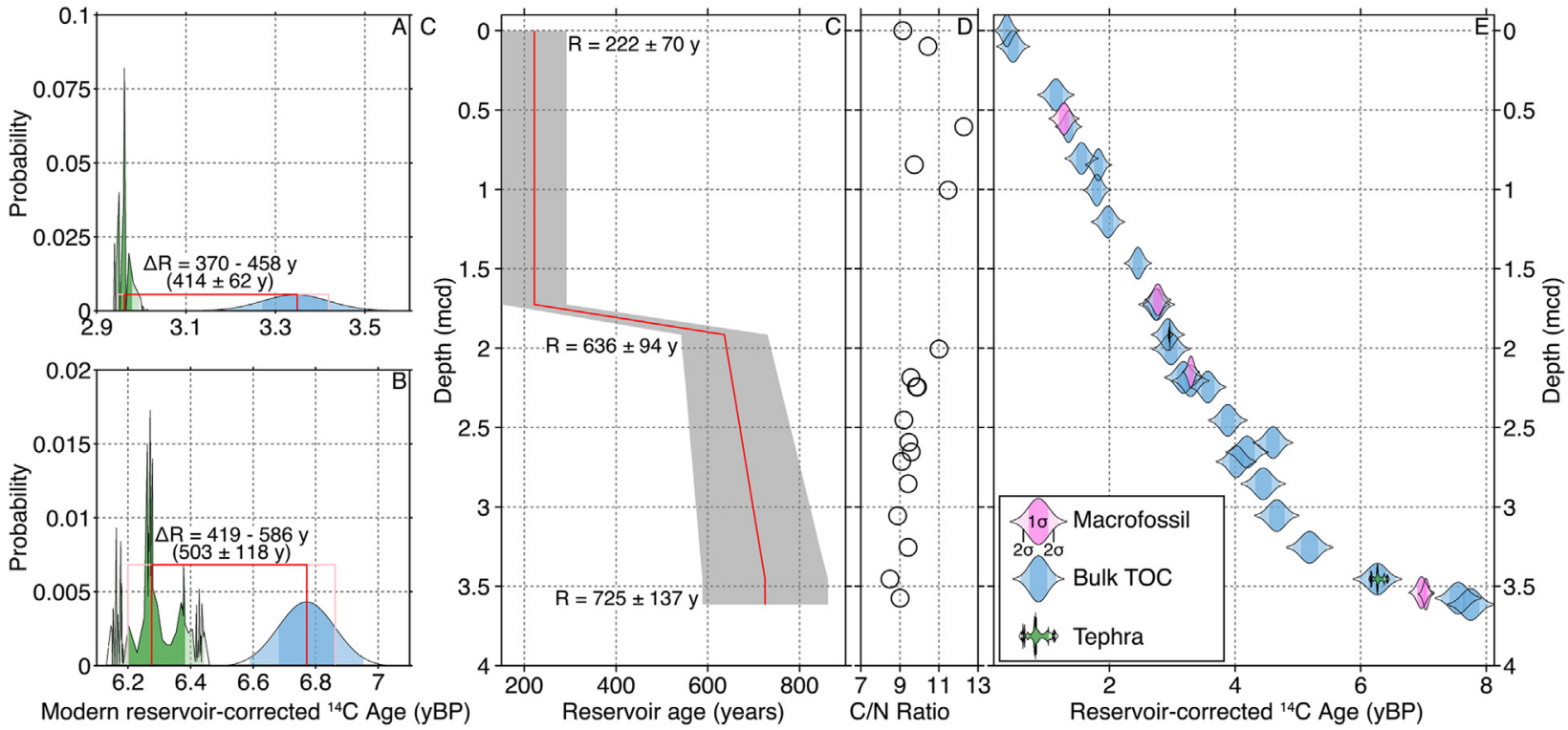

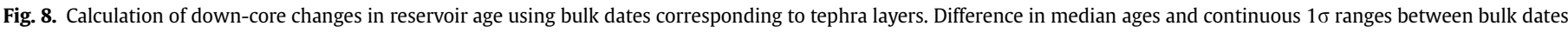

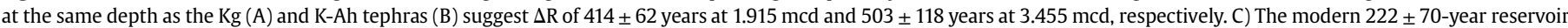

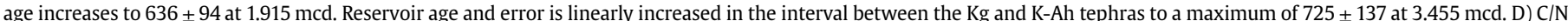

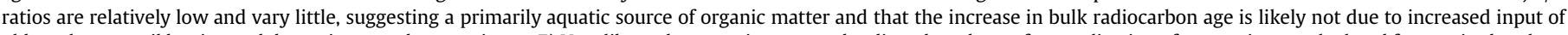

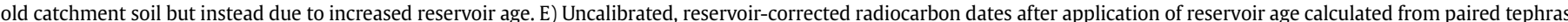

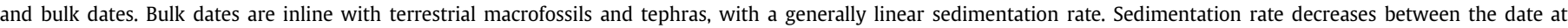
3.245 mcd (YAUT-027503) and the K-Ah tephra. Except for a $\sim 20-\mathrm{cm}$ interval below $2.5 \mathrm{mcd}$, all dates are in stratigraphic order.

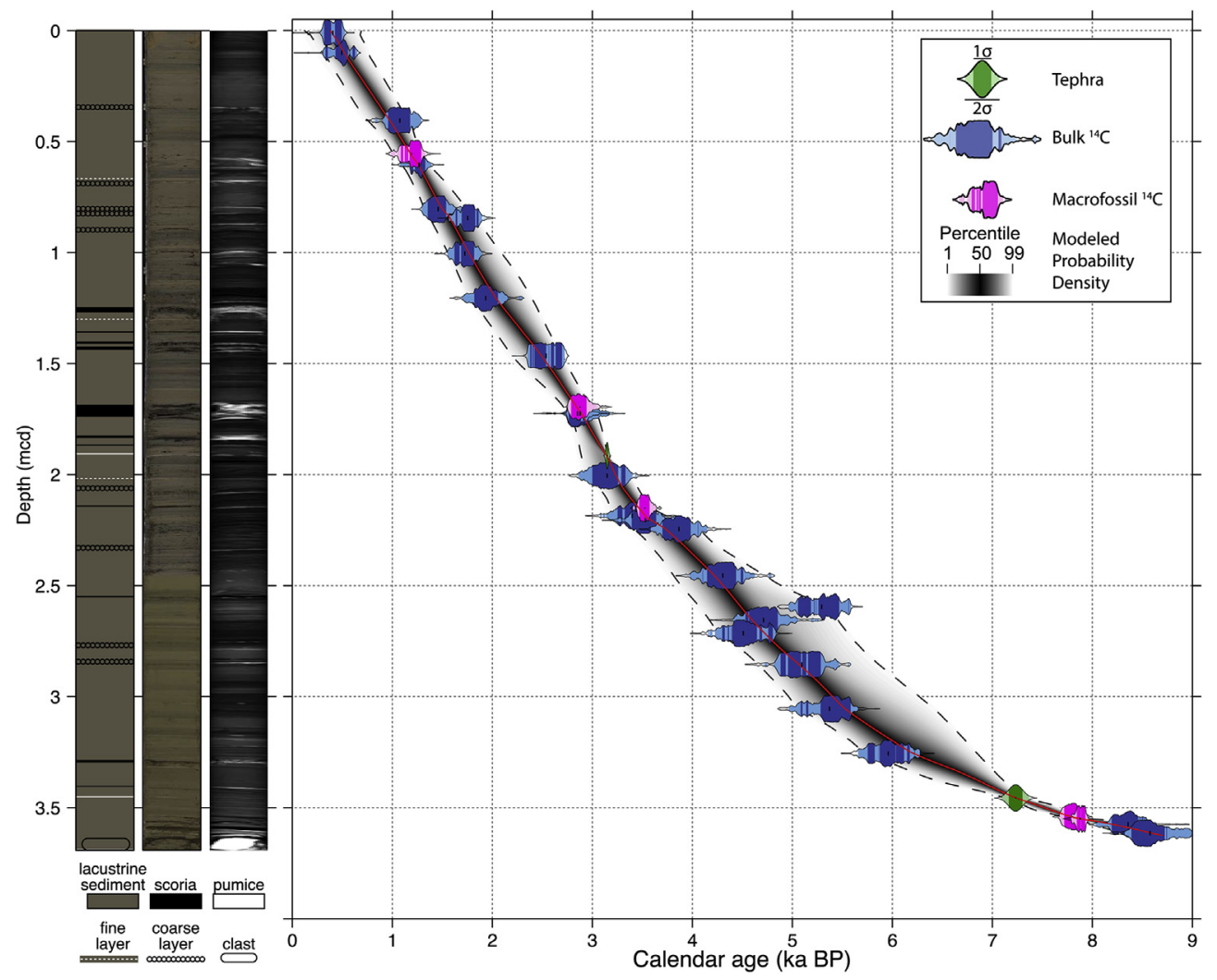

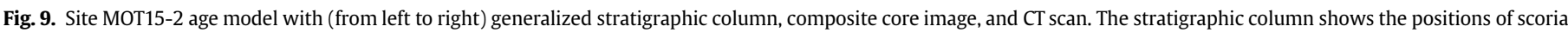

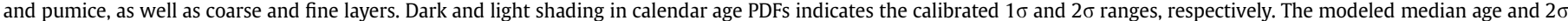

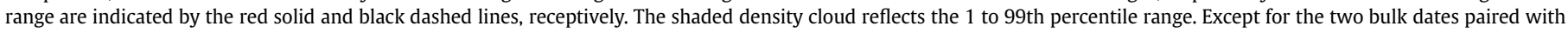

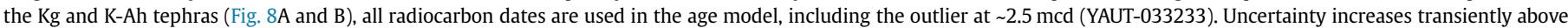

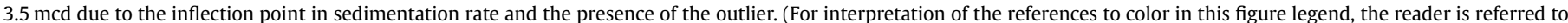
the Web version of this article.) 


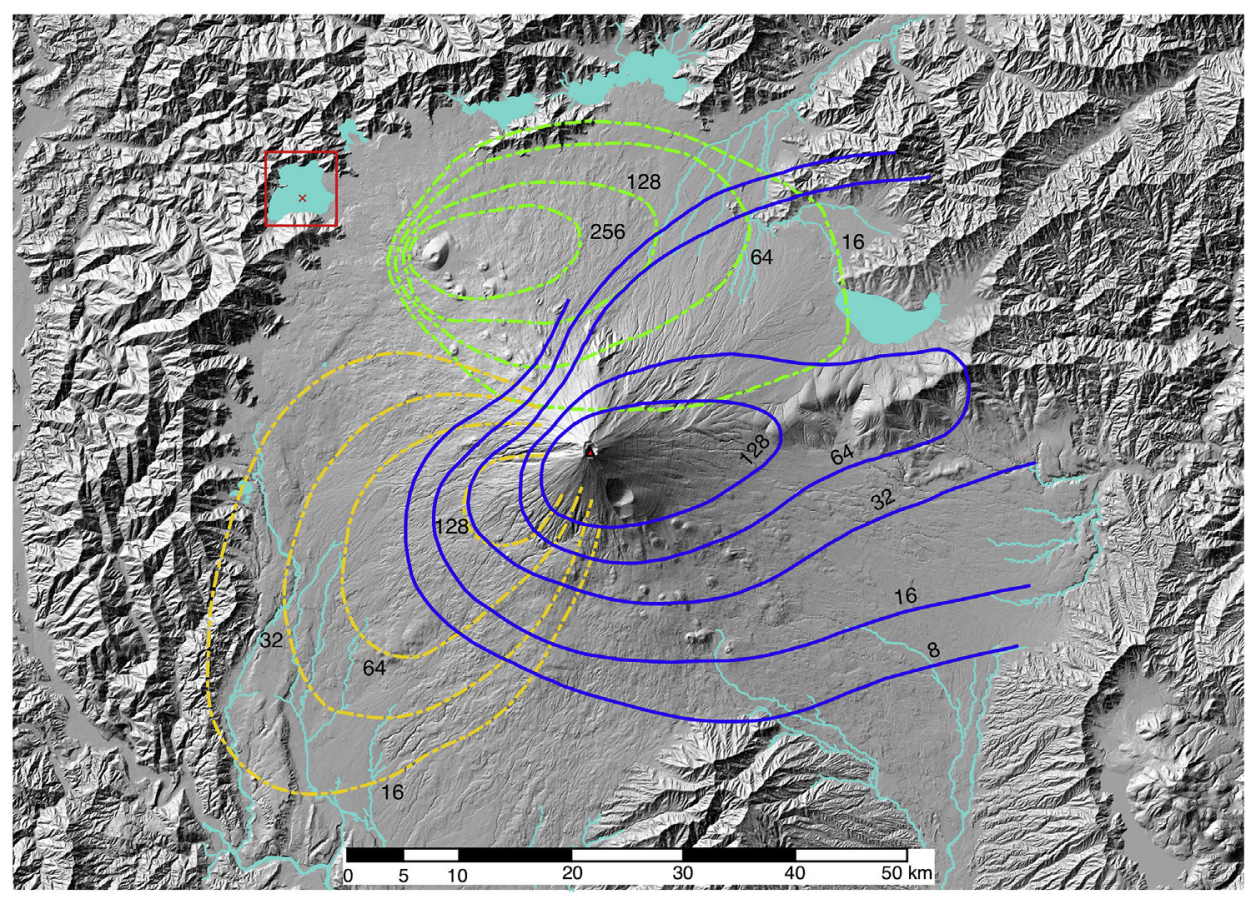

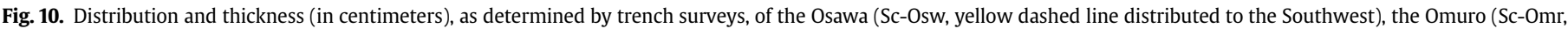

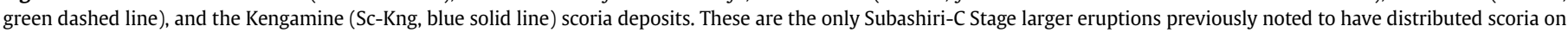

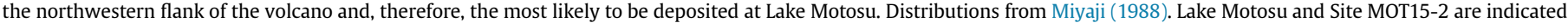
by the box and $\mathrm{X}$ respectively. (For interpretation of the references to color in this figure legend, the reader is referred to the Web version of this article.)

Table 4

Revised ages of eruptions registered in Lake Motosu.

\begin{tabular}{lllll}
\hline Eurption & Symbol & $\begin{array}{l}\text { Modeled Median } \\
\text { Age (cal BP) }\end{array}$ & Modeled 1 $\sigma$ & Modeled 2 $\sigma$ \\
\hline Kengamine & Sc-Kng & 2309 & $2174-2452$ & $2033-2572$ \\
Unknown 2 & Unk2 & 2438 & $2309-2569$ & $2145-2658$ \\
Unknown 1 & Unk1 & 2458 & $2331-2590$ & $2165-2676$ \\
Omuro & Sc-Omr & 2930 & $2859-3003$ & $2798-3072$ \\
Osawa & Sc-Osw & 3042 & $2965-3085$ & $2858-3119$ \\
\hline
\end{tabular}

It is not possible to geochemically identify most individual Mt. Fuji eruptions due to extremely low variability in chemical composition (e.g., Ishizuka et al., 2007). Therefore, we consider the age of each scoria deposit relative to previously published ages (Yamamoto et al., 2005b), reported distribution (Fig. 10), and stratigraphic position relative to the Kg tephra (Fig. 3). Each scoriafall layer deposited at Site MOT15-2 is above the Kg tephra, ruling out the eruptions generating the SYP1 pyroclastic density current and the S-10 scoria.

The oldest scoria-fall layer recovered at MOT15-2 corresponds to the Osawa eruption (Fig. 11). The Osawa directly overlies the Kg tephra, and there are no Mt. Fuji eruptions reported in between. This is consistent with the stratigraphic order preserved at Lake Motosu. Above the Osawa, the next eruption to result in scoria-fall on the northwestern flank was the Omuro. The ages of these two eruptions, originally obtained by dating charred material (Yamamoto et al., 2005b), are recalibrated here for consistency, obtaining $2 \sigma$ age ranges of $3214-3401$ and $3072-3272$ cal BP, respectively (Fig. 3 ). The $2 \sigma$ age ranges for these two eruptions are derived from calibrated ${ }^{14} \mathrm{C}$ ages, which only include ${ }^{14} \mathrm{C}$ measurement error and calibration uncertainty. The revised age ranges sourced from our age-depth modeling also include depth and sedimentation rate uncertainty. For these reasons, the $2 \sigma$ age ranges from the previous study and those from our study are not directly comparable. We therefore also report the $1 \sigma$ ranges below.

Charred material associated with scoria fall are likely to be biased towards older ages, which is the case here since the previously-reported ages are older than the stratigraphically-lower Kg tephra (3149 \pm 12 cal BP; Tani et al., 2013). We therefore propose revising the ages of the Osawa and Omuro eruptions to 3042 $(2965-30851 \sigma)$ and $2930(2859-30031 \sigma)$ cal BP, respectively, the median values obtained from our age model. This suggests a shorter duration between the two eruptions of $\sim 100$ years. The revised age of the Omuro eruption coincides with a large-scale collapse event of unknown origin on the eastern slope (Miyaji et al., 2004), suggesting the latter may be related to simultaneous volcanic activity from other craters of the Fuji volcano. The reworked scoria layer above the Omura fall-layer was deposited $\sim 20$ years following the eruptions.

Correlation of the upper three scoria-fall deposits $(2,458,2,438$, and $2309 \mathrm{cal} \mathrm{BP}$ ) is less certain due to the number of eruptions that occurred since deposition of the Kg tephra. The SYP3 and SYP4 pyroclastic density currents appear to have been produced several hundred years prior, and there was a much longer duration between those two eruptions. There are four relatively large eruptions potentially consistent in age with the two scoria layers, the S-20, S18 , S-17, and S-17'. Of these only the S-18 has been dated (2356-2545 cal BP), but none of these have been reported in this area. Following the Kengamine eruption, the last summit eruption (also known as the Yufune; 2328-2122 cal BP; Yamamoto et al., 2011), several small-scale northwestern flank eruptions occurred. However, the ages of these are not well constrained, and the distributions of ejecta are very limited, typically less than $1 \mathrm{~km}$ from the craters (Ishizuka et al., 2007; Suzuki et al., 2007). Therefore, it is unlikely that these flank eruptions deposited material in Lake Motosu.

Thus, the age of the youngest scoria-fall layer observed in Lake

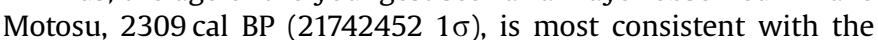




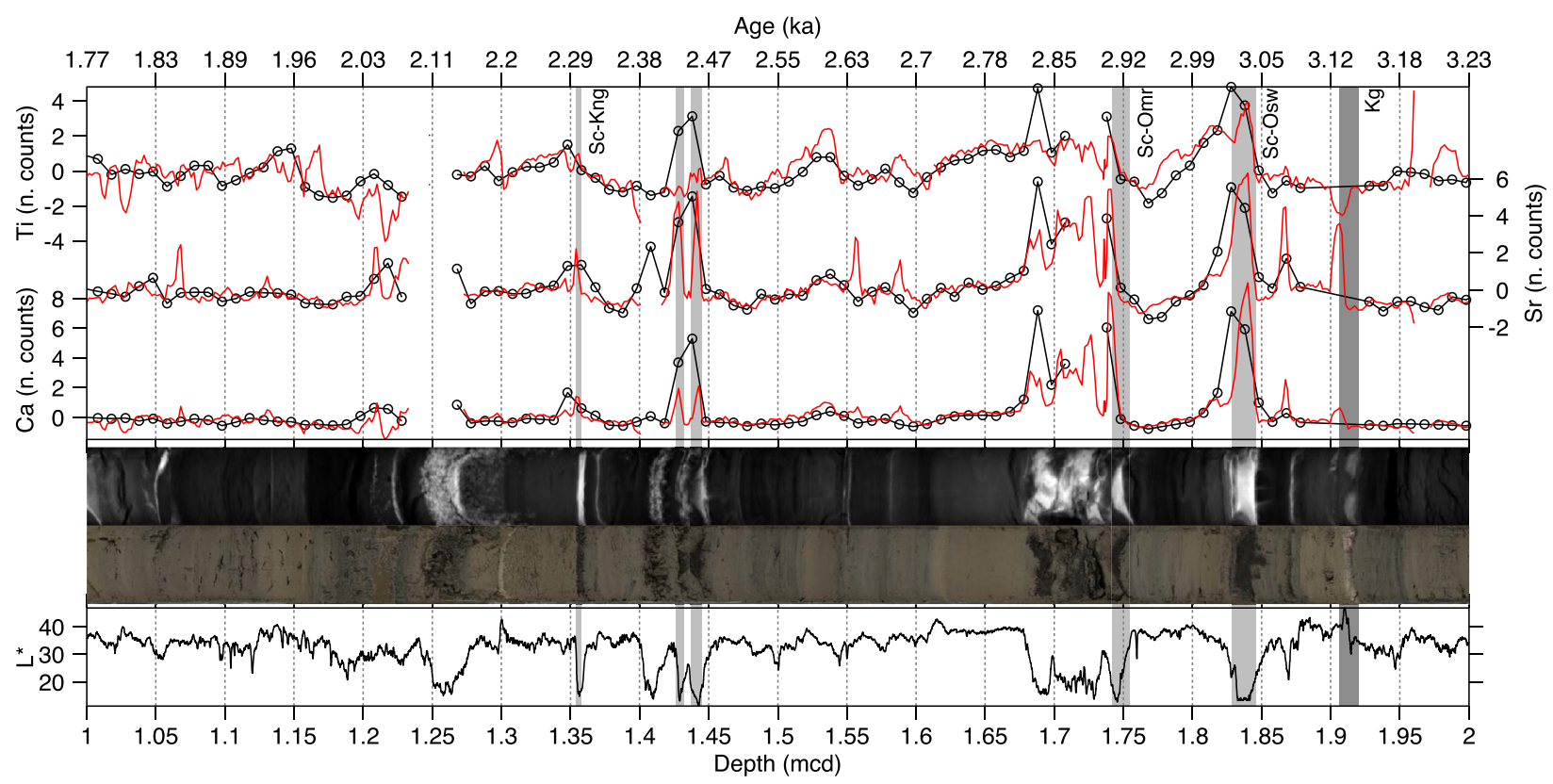

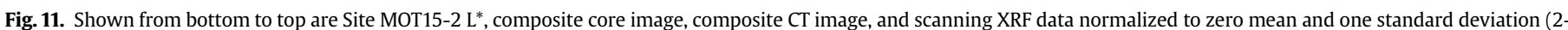

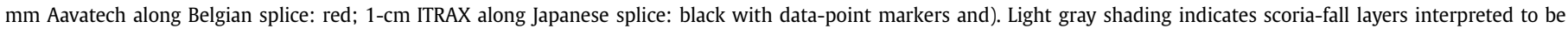

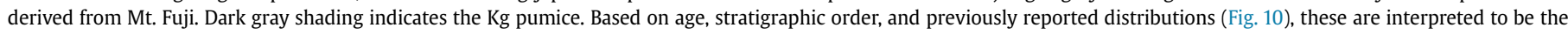

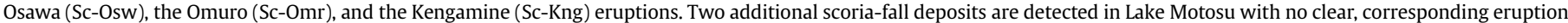
events. (For interpretation of the references to color in this figure legend, the reader is referred to the Web version of this article.)

Kengamine eruption. The two antecedent unknown eruptions preserved in Lake Motosu are older than dates obtained from the Kengamine scoria-associated charred materials. As discussed above, these are typically biased to older ages, and we would therefore expect the ages obtained from the continuouslyaccumulating lacustrine sequence to produce younger, not older, ages. It appears that the ejecta from the Osawa, Omuro, and Kengamine eruptions is more widely distributed than previously thought.

The remaining two scoria-fall layers identified at 2458 (2331-2590 $1 \sigma)$ and $2438(2309-25691 \sigma)$ cal BP have no clear corresponding eruptions with similar age ranges, and it is difficult to determine the origin of these two deposits. They could correspond to previously reported eruptions or represent eruptions undetected until now. The short duration between these two distinct events may be insufficient for significant soil development. Thus, on land, they could appear as a single fallscoria layer, which would have implications for estimating eruption magnitude.

In addition to the possibility of two undetected eruptions, the results presented here provide more accurate ages and indicate a wider distribution of ejecta for the Osawa, Omuro, and Kengamine eruptions during the Subashi-C Stage. Because the distribution of ejecta from previous eruptions indicates the possible affected area during future eruptions, a wider evacuation area should be designated, particularly in the case of eruptions similar to Osawa, Omuro and Kengamine. The more accurate ages reported here, and the implications for eruption frequency, will modify long-term prediction. Thus, these results are relevant to the disaster mitigation plan in the proximity of Mt. Fuji.

\section{Conclusions}

Lakes proximal to volcanoes are powerful tools for comprehensive reconstruction of eruption history. Lacustrine sediments, even when no annual laminations are present, provide a more accurate and precise means of identifying and dating volcanic sediments than traditional land-based surveys, particularly due to steady recording of inter-event time by background sedimentation processes. A robust chronology, anchored by independently dated tephra layers and terrigenous macrofossils, is constructed through high-density radiocarbon dating. The 8000 -year record presented here, from a densely populated region with a large number of annual visitors, reveals potentially previously-undetected Mt. Fuji eruptions, indicates wider distribution of ejecta, and refines the timing of known eruptions. The lacustrine setting allows for clear differentiation of closely spaced events that could otherwise appear as a single larger-magnitude eruption, with implications for estimating the magnitude of past eruptions, long-term prediction, and mitigation planning.

\section{Acknowledgements}

This work is part of the "QuakeRecNankai" project, funded by the Belgian Science Policy Office. Additional funding by JSPS Kakenhi 16K05571, 17H01168, and 15KK0151, as well as the University of Tokyo Atmosphere and Ocean Research Institute program for visiting researchers. We thank Takeshi Nakagawa for discussion of operational strategy and M. Murayama for assistance with XRF scanning. Water samples were provided by Air and Water Preservation Division of Yamanashi Prefecture. A portion of this research used data acquired at the XRF Core Scanner Lab at the MARUM Center for Marine Environmental Sciences, University of Bremen, Germany. Data associated with this study are archived at the Pangaea Data Archive https://doi.pangaea.de/10.1594/PANGAEA. 893286.

\section{Appendix A. Supplementary data}

Supplementary data related to this article can be found at https://doi.org/10.1016/j.quascirev.2018.09.001. 


\section{References}

Bertrand, S., Daga, R., Bedert, R., Fontijn, K., 2014. Deposition of the 2011-2012 Cordón Caulle tephra (Chile, $40^{\circ} \mathrm{S}$ ) in lake sediments: implications for tephrochronology and volcanology. J. Geophys. Res.: Earth Surface 119, 2555-2573. https://doi.org/10.1002/2014JF003321.

Blaauw, M., Christen, J.A., Bennett, K.D., Reimer, P.J., 2018. Double the dates and go for Bayes - impacts of model choice, dating density and quality on chronologies. Quat. Sci. Rev. 188, 58-66. http://www.sciencedirect.com/science/article/ pii/S0277379118301070.

Blaauw, M., van Geel, B., Kristen, I., Plessen, B., Lyaruu, A., Engstrom, D.R., van der Plicht, J., Verschuren, D., 2011. High-resolution 14C dating of a 25,000-year lakesediment record from equatorial East Africa. Quat. Sci. Rev. 30, 3043-3059. http://www.sciencedirect.com/science/article/pii/S0277379111002186.

Björck, S., Rittenour, T., Rosén, P., França, Z., Möller, P., Snowball, I., Wastegård, S. Bennike, O., Kromer, B., 2006. A Holocene lacustrine record in the central North Atlantic: proxies for volcanic activity, short-term NAO mode variability, and long-term precipitation changes. Quat. Sci. Rev. 25 (1), 9-32. https://doi.org/10. 1016/j.quascirev.2005.08.008.

Fuji Hazard Map Committee Members, 2004. Mt. Fuji Hazard Map Committee Report. Cabinet Office, Government of Japan [Japanese]. http://www.bousai.go. jp/kazan/fujisan-kyougikai/report/.

Fujiwara, O., Machida, H., Shiochi, J.-i., 2010. Tsunami Deposit from the 7,300 Cal BP Akahoya Eruption Preserved in the Yokoo Midden, North Kyushu, West Japan. The Quaternary Research(Daiyonki-kenkyu) 23-33 [Japanese]. https://ci.nii.ac. jp/naid/130004509758/en.

Geospatial Information Authority of Japan, 2018. Ministry of Land, Infrastructure Transport and Tourism [Japanese]. http://www.gsi.go.jp/kankyochiri/ koshouchousa-list.html.

Hamada, H., Katshumata, D., Oyagi, H., 2012. Investigation of Seasonal Change of Water Temperature and Water Quality and Water Balance on Lake Motosu-ko: Bulletin of the Faculty of Education, 66. Chiba University, pp. 459-468 [Japanese with English abstract]. http://opac.ll.chiba-u.jp/da/curator/900116225/.

Ishizuka, Y., Takada, A., Suzuki, Y., Kobayashi, M., Nakano, S., 2007. Eruption ages and whole-rock chemistries of scoria cones on the northern to western slope of Fuji Volcano based on trenching surveys. Bull. Geol. Surv. Jpn. 57, 357-376 [Japanese with English abstract]. https://doi.org/10.9795/bullgsj.57.357.

Koshimizu, S., Uchiyama, T., Yamamoto, G., 2007. Volcanic history of Mt. Fuji recorded in borehole cores from Fuji Five Lakes surrounding Mt. Fuji. In: Aramaki, S., Fujii, T., Nakada, S., Miyaji, N. (Eds.), Fuji Volcano. Yamanashi Institute of Environmental Sciences, pp. 365-374 [Japanese with English abstract].

Lamair, L., Hubert-Ferrari, A., Yamamoto, S., El Ouahabi, M., Vander Auwera, J. Obrochta, S., Boes, E., Nakamura, A., Fujiwara, O., Shishikura, M., Schmidt, S. Siani, G., Miyairi, Y., Yokoyama, Y., De Batist, M., Heyvaert, V.M.A., 2018. Volcanic influence of Mt. Fuji on the watershed of Lake Motosu and its impact on the lacustrine sedimentary record. Sediment. Geol. 363, 200-220. http://www. sciencedirect.com/science/article/pii/S0037073817302610.

Lougheed, B.C., Obrochta, S.P., 2016. MatCal: open source bayesian ${ }^{14} \mathrm{C}$ age calibration in MatLab. J. Open Res. Software 4. http://doi.org/10.5334/jors.130.

Lougheed, B.C., Obrochta, S.P., Lenz, C., Mellström, A., Metcalfe, B., Muscheler, R., Reinholdsson, M., Snowball, I., Zillén, L., 2017. Bulk sediment 14C dating in an estuarine environment - how accurate can it be? Paleoceanography 32 1944-9186. https://doi.org/10.1002/2016PA002960.

Lougheed, B.C. and Obrochta, S.P., submitted, A Rapid, Deterministic Age-depth Modelling Routine for Geological Sequences with Inherent Depth Uncertainty: Paleoceanography and Paleoclimatology.

Machida, H., 1977. Kazanbai Wa Kataru (Volcanic Ash Is Telling). Soju Shobo, 249 pp. [Japanese].

Machida, H., Arai, F., 2003. Atlas of Tephra in and Around Japan: Tokyo. University of Tokyo Press, 336 pp. [Japanese].

McLean, D., Albert, P.G., Nakagawa, T., Suzuki, T., Staff, R.A., Yamada, K., Kitaba, I. Haraguchi, T., Kitagawa, J., Smith, V.C., 2018. Integrating the Holocene Tephrostratigraphy for East Asia Using a High-resolution Cryptotephra Study from Lake Suigetsu (SG14 Core), Central Japan. Quaternary Science Reviews 18336-58. http://www.sciencedirect.com/science/article/pii/S0277379117306789.

Miyaji, N., 1988. History of younger Fuji volcano. J. Geol. Soc. Jpn. 94, 433-452 [Japanese with English abstract]. https://doi.org/10.5575/geosoc.94.433.

Miyaji, N., Togashi, S., Chiba, T., 2004. A large-scale collapse event at the eastern slope of Fuji volcano about 2900 Years ago. Bull. Volcanol. Soc. Jpn. 49, 237-248 [Japanese with English abstract]. https://doi.org/10.18940/kazan.49.5_237.

Miyairi, Y., Yoshida, K., Miyazaki, Y., Matsuzaki, H., Kaneoka, I., 2004. Improved 14C dating of a tephra layer (AT tephra, Japan) using AMS on selected organic fractions. In: Nuclear Instruments and Methods in Physics Research Section B: Beam Interactions with Materials and Atoms 223 Proceedings of the Ninth International Conference on Accelerator Mass Spectrometry, pp. 555-559. http://www.sciencedirect.com/science/article/pii/S0168583X04006287.

Nakagawa, T., Gotanda, K., Haraguchi, T., Danhara, T., Yonenobu, H., Brauer, A., Yokoyama, Y., Tada, R., Takemura, K., Staff, R.A., Payne, R., Bronk Ramsey, C., Bryant, C., Brock, F., Schlolaut, G., Marshall, M., Tarasov, P., Lamb, H., 2012. SG06, a fully continuous and varved sediment core from Lake Suigetsu, Japan: stratigraphy and potential for improving the radiocarbon calibration model and understanding of late Quaternary climate changes. Quat. Sci. Rev. 36, 164-176. http://www.sciencedirect.com/science/article/pii/S0277379110004440.

Obrochta, S.P., Andrén, T., Fazeka, S.Z., Lougheed, B.C., Snowball, I., yokoyama, Y., Miyairi, Y., Kondo, R., Kotilainen, A.T., Hyttinen, O., Fehr, A., 2017. The undatables: quantifying uncertainty in a highly expanded Late Glacial - holocene sediment sequence recovered from the deepest Baltic Sea basin - IODP Site M0063. G-cubed 18. https://doi.org/10.1002/2016GC006697.

Obrochta, S.P., Crowley, T.J., Channell, J.E.T., Hodell, D.A., Baker, P.A., Seki, A., Yokoyama, Y., 2014. Climate variability and ice-sheet dynamics during the last three glaciations. Earth Planet Sci. Lett. 406, 198-212. https://doi.org/10.1016/j. epsl.2014.09.004.

Reimer, P.J., Bard, E., Bayliss, A., Beck, J.W., Blackwell, P.G., Ramsey, C.B., Buck, C.E., Cheng, H., Edwards, R.L., Friedrich, M., Grootes, P.M., Guilderson, T.P., Haflidason, H., Hajdas, I., Hatté, C., Heaton, T.J., Hoffmann, D.L., Hogg, A.G., Hughen, K.A., Kaiser, K.F., Kromer, B., Manning, S.W., Niu, M., Reimer, R.W., Richards, D.A., Scott, E.M., Southon, J.R., Staff, R.A., Turney, C.S.M., Plicht, J.V.D., 2013. IntCal13 and Marine13 radiocarbon age calibration curves $0-50,000$ years cal BP. Radiocarbon 55, 1869-1887. https://doi.org/10.2458/azu_js_rc.55.16947.

Smith, V.C. Staff, R.A., Blockley, S.P.E., Bronk Ramsey, C., Nakagawa, T., Mark, D.F., Takemura, K., Danhara, T., 2013. Identification and correlation of visible tephras in the Lake Suigetsu SG06 sedimentary archive, Japan: chronostratigraphic markers for synchronising of east Asian/west Pacific palaeoclimatic records across the last 150 ka. Quat. Sci. Rev. 67, 121-137. http://www.sciencedirect. com/science/article/pii/S0277379113000413.

Sugihara, S., Fukuoka, T., Ookawara, R., 2001. Volcanic eruptions of tenjouzan volcano at Kozushima and Mukaiyama volcano at Niijima, Izu islands. J. Geogr. 100, 94-105. https://doi.org/10.5026/jgeography.110.94.

Suzuki, Y., Takada, A., Ishizuka, T., Kobayashi, M., 2007. Reexamination of the eruptive history of scoria cones on the northwestern foot of Fuji volcano. Bull. Geol. Surv. Jpn. 57, 337-385. https://doi.org/10.9795/bullgsj.57.377.

Suzuki, Y., Yasuda, A., Hokanishi, N., Kaneko, T., Nakada, S., Fujii, T., 2013. Syneruptive deep magma transfer and shallow magma remobilization during the 2011 eruption of Shinmoe-dake, Japan-constraints from melt inclusions and phase equilibria experiments. J. Volcanol. Geoth. Research 257184-204 http:// www.sciencedirect.com/science/article/pii/S0377027313000930.

Takada, A., Yamamoto, T., Ishizuka, Y., Nakano, S., 2016. Geological Map of Fuji Volcano (Second Edition) with Explanatory Text: Miscellaneous Map Series, 12, p. 56 [Japanese with English abstract]. https://www.gsj.jp/Map/EN/docs/misc doc/misc 12 2nd.html.

Tani, S., Kitagawa, H., Hong, W., Par, J.H., 2013. Age determination of the Kawagodaira volcanic eruption in Japan by $14 \mathrm{C}$ wiggle-matching. Radiocarbon 55 , 748-752. https://journals.uair.arizona.edu/index.php/radiocarbon/article/view/ 16312 .

Tsuya, H., 1968. Geology of Volcano Mt. Fuji. Explanatory Text of Geological Map 1: 50,000 Scale: Geological Survey of Japan [Japanese with English abstract].

Van Daele, M., Moernaut, J., Silversmit, G., Schmidt, S., Fontijn, K., Heirman, K., Vandoorne, W., De Clercq, M., Van Acker, J., Wolff, C., Pino, M., Urrutia, R., Roberts, S.J., Vincze, L., De Batist, M., 2014. The 600 yr Eruptive History of Villarrica Volcano (Chile) Revealed by Annually Laminated Lake Sediments, 126. Geological Society of America Bulletin, pp. 481-498. https://doi.org/10.1130/ B30798.1.

Webster, J.M., Braga, J.C., Humblet, M., Potts, D.C., Iryu, Y., Yokoyama, Y., Fujita, K., Bourillot, R., Esat, T.M., Fallon, S., Thompson, W.G., Thomas, A.L., Kan, H., McGregor, H.V., Hinestrosa, G., Obrochta, S.P., Lougheed, B.C., 2018. Response of the Great Barrier Reef to sea-level and environmental changes over the past 30,000 years. Nat. Geosci. 11, 426-432. https://doi.org/10.1038/s41561-0180127-3.

Yamamoto, T., Nakano, S., Takada, A., Kobayashi, M., 2011. New stratigraphy of recent eruption products on the eastern slope of the Mt. Fuji volcano. Bull. Geol. Surv. Jpn. 62, 405-424 [Japanese with English abstract]. https://doi.org/10. 9795/bullgsi.62.405.

Yamamoto, T., Takada, A., Ishizuka, Y., Miyaji, N., Tajima, Y., 2005a. Basaltic pyroclastic flows of Fuji volcano, Japan: characteristics of the deposits and their origin. Bull. Volcanol. 67, 622-633. https://doi.org/10.1007/s00445-004-0398-

Yamamoto, T., Takada, A., Ishizuka, Y., Nakano, S., 2005b. Chronology of the products of Fuji volcano based on new radiometric carbon ages. Bull. Volcanol. Soc. Jpn. 50, 53-70 [Japanese with English abstract]. https://doi.org/10.18940/kazan.50. 2_53.

Yamane, M., Yokoyama, Y., Miyairi, Y., Suga, H., Matsuzaki, H., Dunbar, R.B., Ohkouchi, N., 2014. Compound-specific 14C dating of IODP expedition 318 core U1357A obtained off the wilkes land coast, Antarctica. Radiocarbon 56, 1009-1017. https://journals.uair.arizona.edu/index.php/radiocarbon/article/ view $/ 17773$.

Yokoyama, Y., Anderson, J.B., Yamane, M., Simkins, L.M., Miyairi, Y., Yamazaki, T. Koizumi, M., Suga, H., Kusahara, K., Prothro, L., Hasumi, H., Southon, J.R., Ohkouchi, N., 2016. Widespread collapse of the ross ice shelf during the late holocene. Proc. Natl. Acad. Sci. Unit. States Am. 113, 2354-2359. http://www. pnas.org/content/113/9/2354.abstract. 